ESJ Social Sciences

\title{
Strategy Map Development for the Central Bank of Nepal Using Balanced Scorecard
}

\author{
Shova Niroula, MA \\ Qingmei Tan, PhD \\ Nanjing University of Aeronautics and Astronautics, China \\ Aswin Parajuli, MBA \\ Kathmandu University School of Management, Nepal
}

Doi:10.19044/esj.2021.v17n1p88

Submitted: 21 October 2020

Accepted: 08 January 2021

Published: 31 January 2021
Copyright 2021 Author(s)

Under Creative Commons BY-NC-ND

4.0 OPEN ACCESS

Cite As:

Niroula S., Tan Q. \& Parajuli A. (2021). Strategy Map Development for the Central Bank of Nepal Using Balanced Scorecard. European Scientific Journal, ESJ, 17(88), 88. https://doi.org/10.19044/esj.2021.v17n1p88

\section{Abstract}

This paper focuses on how the development of the strategy map for the Central Bank of Nepal is done by linking the key measures with the four perspectives of Balanced Scorecard perspectives (finance, customer, internal process, and learning and growth). The central bank is a vital part of an economy, and therefore it should not limit its strategy implementation and performance measurement within the financial perspectives only. So, this paper serves the purposes of creating a road map for discovering the key indicators to create the strategy map and to support future research in the Nepalese banking field. In the absence of a previous strategy map, the strategic goals of the bank were derived from the relevant literature, the bank's vision, mission, goals, and mandates followed by the expert's selection. A list of the bank's strategic goals was derived from the survey questionnaire corresponding to the four perspectives of Balanced Scorecard. The measures of perspective were studied by factor analysis. The research therefore uses a descriptive-exploratory method. Finally, the strategy map was developed and the result consisted of the strategic goals and measures in financial, customer, internal process, and learning and growth.

Keywords: Balanced Scorecard, Central Bank, Strategy mapping 


\section{Introduction}

After questioning contemporary management accounting in several articles during the 1980s, Kaplan and Norton (1992) introduced the Balanced Scorecard (BSC) concept. BSC translates an organization's mission and strategy into a comprehensive set of performance measures to provide the necessary framework for a strategic measurement and management system (Kaplan \& Norton, 1996). According to Kaplan and Norton, an effective strategic learning process requires a shared strategic framework that communicates the strategy and allows all participants to see how their individual activities contribute to achieving the overall strategy. Thus, the BSC provides a representation of the organizations' shared vision.

Since banking institutions hold the intangible nature of products and services, it can be challenging to measure the efficiency of the institutions. Many traditional measures focus mainly on the financial aspects during the strategy implementation and performance assessment.

To screen strategy implementation constantly, a Balanced scorecard can be used for developing proper strategic goals and their measures (Norton, 2009). Since its development, BSC has evolved as the bridge between leading and lagging factors which helps in converting the organization's strategy into actions. With the introduction of the Strategy map, organizations have been able to scientifically construct their management system around their strategies (Kaplan \& Norton, 2004). Since then, BSC has not been limited only to the performance measurement but has also been rebuild as the means that helps in implementing the strategies and in presenting strategy mapping which defines the various ways of executing the strategies. Even though many BSC studies have limited themselves in performance measurement, many banking and other organizations nowadays have been widely using BSC as a successful measure to execute strategic plans (Aranda \& Arellano, 2010; Banker et al., 2004). Central Bank of Nepal is the national-level regulatory authority whose importance is immense for the nation. Due to the rapid financial sector liberalization, the financial sector has become more agile which has raised various challenges to the Central Bank to attain macroeconomic and financial stability. In such a scenario, the bank should adapt its strategy accordingly so that the institute can cope up with the latest world development. However, the bank has been focusing on financial aspects for planning and performance measurement. Many studies on Balanced Scorecard have been done in Nepal previously but no documented strategy map or key performance indicators (KPIs) could be found for the non-financial perspectives for the bank. So, this study aims to fill in the gap prevailing in this field, It also aims to create a path for future research on strategy mapping and on BSC as an alternative performance measurement tool. 
This study uses the survey method and literature review to obtain the data regarding the bank's strategic goals and measures. The bank's KPIs and measures are based on the four perspectives of BSC. In addition to this, factor analysis is also conducted to validate the study. This paper follows the basic structure starting from the abstract followed by the introduction, literature review, Central Bank of Nepal, methodology, research findings, and conclusions. The map of the article followed in this research is shown in the figure below:

Figure 1. Map of article

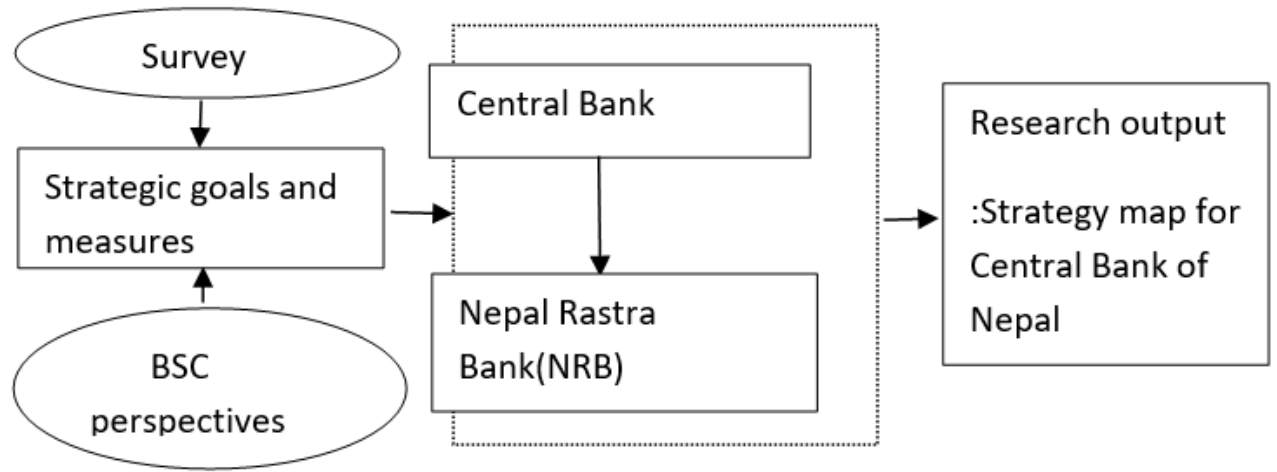

In conclusion, the study mainly focuses on 1) exploring and organizing the strategic goals and measures suitable for the performance evaluation of the Central Bank of Nepal (Nepal Rastra Bank) based on BSC perspectives; 2) developing a strategy map for strategical improvements; 3) arranging suggestions based on the analysis and providing assistance for future research.

\section{Literature Review}

In the year 1992, Kalpan and Nortan developed a performance tool that allowed the managers to view the organization from four perspectives: financial, customers, internal process, and learning and growth. They later introduced 'Strategy mapping' as a business architecture discipline which helped in implementing strategies. Balanced scorecard perspectives do not only focus on the financial goals of the organization but also focuses on the non-financial goals which help the organization to meet the strategy required to lead the industry.

Frigo et al. (2000) described the use of four perspectives to implement the vision and strategy for the community banks. However, other studies also used balanced scorecard perspectives for performance measurement along with strategy development (Banker et al., 2004; Aranda \& Arellano, 2010).

Many studies have been researched in the banking industries using BSC and strategy map. Among these studies, many focus only on performance measurement rather than finding the key performance indicators for the implementation of the strategy. Wu et al. (2011) focus on how the BSC should 
not be limited as a performance measurement tool but also should be utilized in the construction of a strategy map focused on the development of the organization.

A model was developed by Zhang and $\mathrm{Li}$ (2009) which studied the four perspectives of BSC in commercial banks. Wu (2012) researched the strategy map of the balanced scorecard as a structural evaluation methodology for a bank. In the same study, KPIs were linked to create a strategy map by determining the causal relationship between them. This study not only created the framework for the construction of the strategy map but also showed the path of creating a strategy map for the banking intuitions.

Abdurizzag Abofaied (2017) developed the BSC for a bank in Libya to measure the performance of the bank. This study helps in understanding the concept of BSC development and also enhances the cause-effect relationship between the financial and non-financial aspects of the organization.

Similarly, Ahmed Hamdy (2018) examined the effect of the bank orientation by the balanced scorecard approach on the bank's performance and competitiveness. The result of the study implied that the BSC approach has a significant impact on banking performance as well as competitiveness.

On the other hand, Miklós Pakurár et al. (2019) conducted an empirical study on the impact of supply chain integration on organizational performance in the Jordanian banking sector using the balanced scorecard approach. The result not only showed the significant relationship between the supply chain integration and organizational performance but also suggested the improvement of customer involvement to improve the bank's performance.

Due to the agile and non-profit oriented characteristics of the nonprofit organization, the development of a strategy map can be tricky at times. Cam Scholey and Kurt Schobel (2016) published a paper where they outlined a possible approach to strategy execution. This is a four-step framework named performance measurement for non-profits (PM4PNO) which uses the Balanced Scorecard approach.

In October 2004, a strategy map for the Central Bank of Indonesia was published after the long study which started in the year 2001 as a plan to launch inclusive planning of performance measurement (Djafara \& Pranoto, 2004). The result is shown in Figure 2. 
Figure 2. Strategy map for Bank of Indonesia

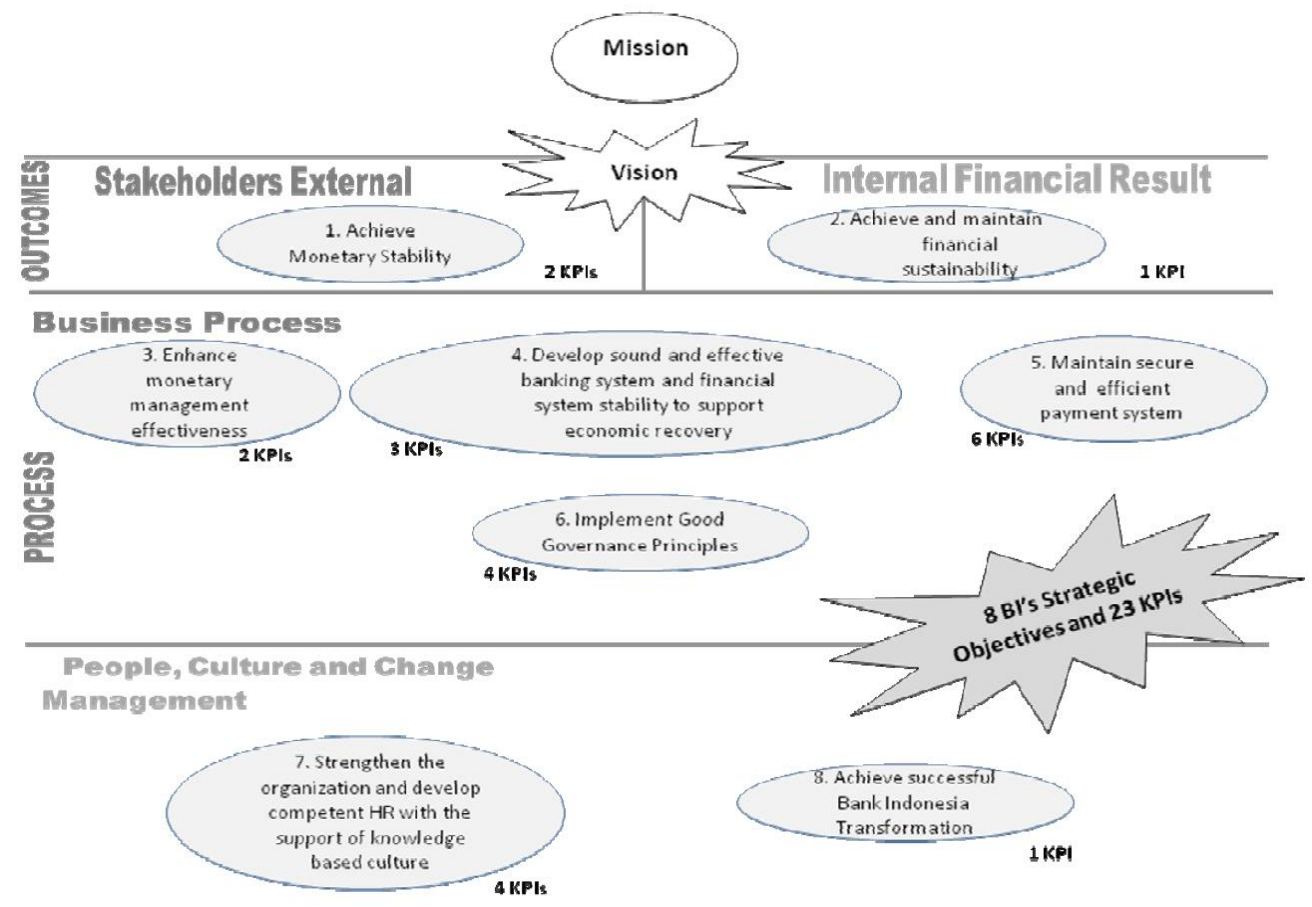

Mojtaba et al. (2011) did a study for the Central Bank of Iran to develop the strategy map. The result created the strategy map for the bank which is focused on clarity of the strategic goals for the bank.

For any organization to develop the relevant strategy map, proper KPIs should be selected after the rigorous literature review along with the expert's selection. Improved SWOT analysis was used as a method for finding the strategic goals by Quezada et al. (2009) to identify the KPIs. Rule of thumb is also often used in the strategy mapping process. Littler et al. combined the strategy formulation perspective of Hamel and Prahalad (1996a, 1996b) with the BSC method of Kalpan and Norton (1996). Quezada (2009) describes a simple tool to identify the strategic objectives in creating a strategy map by studying three types of methods.

In the context of Nepal, many studies have been conducted on BSC but no documented article on the strategy map has been found. Ghanendra Fago (2010) researched by comparing the performance of two different banking organizations using a Balanced Scorecard.

The central bank is crucial in the financial system and they have different performance measurement issues (Deimante Teresienė, 2018). Satya Narayan Kalika (2019) published an article on 'Evolutionary Overview of Central Banking in Nepal: An Account of Law and Practice' where he explains 
the sequential development of the Central Bank of Nepal. In the same study, the issues revolving around the autonomy of the central bank are mentioned.

\section{Central Bank of Nepal}

Nepal Rastra Bank (Central Bank of Nepal) was established on 26th April 1956 as the Central Bank of Nepal as per the Nepal Rastra Bank (NRB) Act 1955. Since the establishment of the bank, there has been substantial development in the banking field.

The functions and objectives of the bank were reformed by the new Nepal Rastra Bank Act, 2058 (2002), which are:

- to formulate necessary monetary and exchange policies to take care of the steadiness in price and consolidate the balance of payments for sustainable development of the economy;

- to develop a secure, healthy, and efficient system of payments;

- to form appropriate supervision of the banking and economic system to take care of its stability and foster its healthy development;

- to further enhance the general public confidence in Nepal's entire banking and economic system.

The bank is eminently aware that for the achievement of the above objectives within the present dynamic environment, sustained progress and continued reform of the financial sector is of utmost importance. Continuously being conscious of this great responsibility, NRB is seriously pursuing various policies, strategies, and actions, all of which are conveyed within the annual report on monetary policy (Central Bank of Nepal website).

However, the implemented strategy used by Nepal Rastra Bank to meet recent world development needs to be taken into consideration. Nepal is a landlocked country which borders within two of the biggest economy of the world, India and China. The fact that Nepalese currency is pegged with Indian currency is another undeniable truth of the Nepalese economy. In the era of digital banking and digital money, India as a neighboring country is aggressively working on digital payment. Another neighbor country, China, is trying to get yuan to be internationally recognized; thus, they are pushing this operation forward with the introduction of the Chinese Central Bank Digital Currency (CBDC) called DCEP. However, Nepal has a complete ban on cryptocurrency along with no infrastructure to support it. Also, the Nepalese banking industry still seems to struggle with basic mobile and online banking. At this pace, Nepal might end up in monetary conflict internationally without the proper strategy. Depending on these factors, NRB needs to have a detailed strategic plan if it wants to prevent its economy from being outdated or left behind. 
Therefore, the Central Bank's (NRB) supervision capability should be further strengthened to bring it to global standards, which can be done through the help of a strategy map and balanced scorecard.

\section{Methodology}

This study deals with the qualitative data by exploring the prevailing situation without changing any variables. Therefore, this study uses a descriptive survey.

This study mainly looks into the Central Bank of Nepal's vision and mission on two levels. The first level is done by studying the bank's vision, mission, economic development plans, and the bank's related acts and laws. In addition to this, a key informant survey was conducted with the groups of experts consisting of bank managers and related academicians. Based on the initial key informant survey, another questionnaire on the proposed measures by using a five-choice questionnaire was prepared. Since this research is mainly focused on finding the balanced evaluation measures and to develop the strategy mapping, it ensures that the surveyed population should have extensive knowledge of the strategic goals of the bank. The respondents were selected on the basis of strata developed for three (3) sectors: Central Bank of Nepal's employees, Nepalese Commercial Banks middle and top-level managers, and academicians on the basis of academics and professional experience.

In the first phase of the survey, an online survey was done with nine top and middle-level managers and academicians to determine the strategic goals of the Central Bank of Nepal. The first survey was a key informant survey. For the second survey, the statistical population for determining the measures related to the strategic goals derived was composed of 100 respondents. The sampling population for this survey was selected from the random sampling among the strata created on the three (3) sectors as mentioned above.

The first questionnaire consisting of 10 questions was used to find the strategic goals of the bank. This questionnaire included one yes/no question, one four-choice answer question, and five open-end questions. After that, another questionnaire was developed which consists of 63 questions that included the measures related to the previously derived goals. This final questionnaire consists of a five-choice answer question of the spectrum of Likert.

In this research, factor analysis was used to validate the questionnaire, and it also uses Cronbach's alpha $(\alpha)$ to test the reliability of the measures' questionnaire using the SPSS software. Both studies showed that our research study is coordinated enough. Also, the previous studies and research done on the field backups the validity of our methodology and questionnaire. Mojtaba 
et al. (2011) conducted a study for the strategy map creation of the Central Bank of Iran with a similar function. The practice established by this research is followed by this research.

\section{Research Findings}

This study undergoes strategic analysis for the Central Bank of Nepal using a balanced scorecard. The vision, mission, and strategic goals of the bank were determined for the development of the strategy map.

Here, in this exploration, Cronbach's alpha $(\alpha)$ coefficient is conducted to test the consistency of the measures' questionnaire (see Table 1).

Factor analysis was also used to analyze the scale. Therefore, three important stages of factor analysis to consider are:

1) Preparation of correlation matrix

2) Extraction of primary factors

3) Rotating factor to achieve the final solution

Table 1. Reliability test

Cronbach's Alpha Cronbach's Alpha Based on Standardized Items .955 .956 Number of Items 63

The Bartlett test is used to assess the reliability of the fact that the matrix of data in society is not equal to zero. In the present study, the characteristic of the Bartlett-test is significant, indicating that the correlation matrix of the data is not zero in the society. Hence, the operating operation can be justified (see Table 2).

Table 2. Result of KMO and Bartlett test

\begin{tabular}{cccc}
\hline \multicolumn{2}{c}{ Kaiser-Meyer-Olkin Measure of Sampling Adequacy } & .626 \\
\hline Bartlett's Test of & Sphericity & Approx. & Chi-Square \\
& & Df & 4185.841 \\
& & Sig. & 1953 \\
& & & .000 \\
\hline
\end{tabular}

The resulting structure matrix, after 24 rotations, showed the factor loading of the questions and the set of questions which were initially divided into 17 factors. These factors were classified into four basic categories after removing unrelated and low-factor loading questions. This research conclusion obtained the strategic goals and their respective measures for the Central Bank of Nepal on the basis of the scale analysis by factor analysis method (see Table 3). Hence, the strategy map for the Central Bank of Nepal was constructed using our research conclusion as mentioned above (see Figure 2). 
Table 3. Research results

\begin{tabular}{|c|c|c|}
\hline Perspectives & Goals & Measures \\
\hline Financial & $\begin{array}{l}\text { Inflation controlling } \\
\text { and Currency Value } \\
\text { retaining }\end{array}$ & $\begin{array}{ll}\text { - } & \text { Bank interest rate } \\
\text { - } & \text { Liquidity ratio } \\
\text { - } & \text { Cash reserve ratio }(\mathrm{CRR}) \text { of BFIs } \\
\text { - } & \text { Consumer price index }\end{array}$ \\
\hline Financial & $\begin{array}{l}\text { Money supply } \\
\text { controlling (yearly) }\end{array}$ & $\begin{array}{ll}\text { - } & \text { Current ratio } \\
\text { - } & \text { Bank interest rate }\end{array}$ \\
\hline Financial & $\begin{array}{l}\text { External sector } \\
\text { stability }\end{array}$ & $\begin{array}{ll}\text { - } & \text { External debt } \\
\text { - } & \text { Balance of trade (BOT) } \\
\text { - } & \text { Balance of payment (BOP) } \\
\text { - } & \text { Foreign Direct Investment (FDI) } \\
\text { - } & \text { International Investment Position (IIP) }\end{array}$ \\
\hline Customer & $\begin{array}{l}\text { Financial sector } \\
\text { Development and } \\
\text { stability }\end{array}$ & $\begin{array}{l}\text { - The growth of country's banks } \\
\text { - The growth of foreign banks } \\
\text { - The growth of new financial } \\
\text { institutions } \\
\text { - The degree of privatization of } \\
\text { Government banks } \\
\text { - Robust Anti-Money laundering (AML) } \\
\text { / Combating the financing of terrorism } \\
\text { (CFT) } \\
\text { - Payment gateway development } \\
\text { - Access to finance at remote } \\
\text { location/Branchless Banking }\end{array}$ \\
\hline Customer & $\begin{array}{l}\text { Facilitating } \\
\text { monetary and } \\
\text { foreign exchange in } \\
\text { interbank markets }\end{array}$ & 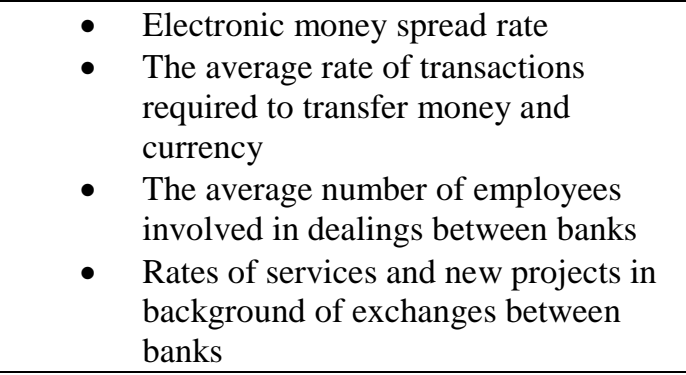 \\
\hline $\begin{array}{l}\text { Internal } \\
\text { process }\end{array}$ & $\begin{array}{l}\text { Maintenance of } \\
\text { NRB's autonomy }\end{array}$ & $\begin{array}{l}\text { The rate of change in Bank's central } \\
\text { management } \\
\text { - Change in NRB's central management } \\
\text { with respect to change in government } \\
\text { - Governor turnover rate }\end{array}$ \\
\hline $\begin{array}{l}\text { Internal } \\
\text { process }\end{array}$ & $\begin{array}{l}\text { Implementation of } \\
\text { knowledge } \\
\text { management and } \\
\text { good governance } \\
\text { system }\end{array}$ & $\begin{array}{ll}\text { - } & \text { Growth of IT costs to current bank } \\
\text { - } & \text { Grosts } \\
\text { - } & \text { Number of internal promotions } \\
\text { - } & \text { Output based incentive }\end{array}$ \\
\hline
\end{tabular}




\begin{tabular}{|c|c|c|}
\hline $\begin{array}{l}\text { Learning and } \\
\text { growth }\end{array}$ & $\begin{array}{l}\text { Organizational } \\
\text { improving and HR } \\
\text { capacity building }\end{array}$ & $\begin{array}{l}\text { - The amount of in-service training on } \\
\text { the bank day } \\
\text { - } \quad \text { Ratio of training hours to average } \\
\text { working hours } \\
\text { - Number of workshops and training } \\
\text { - } \quad \text { Opportunities for higher study on study } \\
\text { leave } \\
\text { - Training budget } \\
\text { - Research and survey budget } \\
\text { - Employees turnover rate } \\
\text { - Inter-department trainings and } \\
\text { meetings }\end{array}$ \\
\hline
\end{tabular}

\section{Conclusion}

The development of a strategy for a non-profit organization and governmental organization is quite different from the non-governmental organization and for-profit organization. They require macro-level planning and documents, which is why this study had to conduct a key informant survey. Many non-profit organization and governmental organization may find complications while studying their financial perspective due to the need of macro-level understanding and their volatile characteristics. Nonetheless, this research found some measurable financial measures which control its overall goals.

The major contribution of our study in the Nepalese banking industry is that a strategy map was created based on the strategic goals derived from the micro and macro-level study, expert's opinion, and survey. Due to the COVID-19 pandemic, practical actions and approaches were limited, which could have made significant help in this study. The surveys and studies were limited to the virtual spaces due to the pandemic. 
Figure 3. Strategy map for Central Bank of Nepal

\begin{tabular}{|c|c|c|}
\hline \multicolumn{3}{|c|}{ Vision: To become "A modern, dynamic, credible and effective Central Bank" } \\
\hline \multicolumn{3}{|l|}{ Financial Perspectives: } \\
\hline $\begin{array}{l}\text { Inflation controlling and } \\
\text { Currency Value retaining }\end{array}$ & Money supply co & External sector stability \\
\hline $\begin{array}{l}\text {-Bank interest rate } \\
\text {-Liquidity Ratio } \\
\text {-Cash reserve ratio of BFIs } \\
\text {-Consumer price index }\end{array}$ & $\begin{array}{l}\text {-Current Ra } \\
\text {-Bank inter }\end{array}$ & $\begin{array}{l}\text {-External debt } \\
\text {-Balance of Trade } \\
\text {-Balance of Payment } \\
\text {-Foreign Direct Investment } \\
\text {-International investment position }\end{array}$ \\
\hline \multicolumn{3}{|c|}{ Customer Perspectives: } \\
\hline \multicolumn{2}{|c|}{ Financial sector Development and stability } & $\begin{array}{l}\text { Facilitating monetary and foreign exchange in } \\
\text { interbank markets }\end{array}$ \\
\hline \multicolumn{2}{|c|}{$\begin{array}{l}\text {-The growth of country's banks } \\
\text {-The growth of new financial institutions } \\
\text {-The growth of foreign banks } \\
\text {-The degree of privatization of Government banks } \\
\text { - Robust Anti-Money laundering/Combating the - } \\
\text { Financing of terrorism } \\
\text {-Payment gateway development } \\
\text {-Access to finance at remote location/Branchless- } \\
\text { Banking }\end{array}$} & $\begin{array}{l}\text {-Electronic money spread rate } \\
\text {-The average rate of transactions required to - } \\
\text { transfer money and currency } \\
\text { - The average number of employees involved in } \\
\text { dealings between banks } \\
\text {-Rates of services and new projects in background } \\
\text { of exchanges between banks }\end{array}$ \\
\hline \multicolumn{2}{|c|}{ Internal Process Perspectives: $\uparrow$} & 4 \\
\hline \multicolumn{2}{|c|}{ Maintenance of NRB's autonomy } & $\begin{array}{l}\text { Implementation of Knowledge management } \\
\text { and good governance system }\end{array}$ \\
\hline \multicolumn{2}{|c|}{$\begin{array}{l}\text {-The rate of change in Bank's central management } \\
\text {-Change in NRB's central management with respect- } \\
\text { to change in government } \\
\text {-Governor turnover rate }\end{array}$} & $\begin{array}{l}\text {-Growth of IT costs to current bank costs } \\
\text {-Growth of cost of IT to the total cost. } \\
\text {-Number of internal promotions } \\
\text {-Output based incentive }\end{array}$ \\
\hline \multicolumn{3}{|c|}{ Learning and growth Perspectives: } \\
\hline \multicolumn{3}{|c|}{ Organizational improving and HR capacity building } \\
\hline \multicolumn{3}{|c|}{$\begin{array}{l}\text {-The amount of in-service training on the bank day } \\
\text {-Ratio of training hours to average working hours } \\
\text {-Number of workshops and training } \\
\text {-Opportunities for higher study on study leave } \\
\text {-Training budget } \\
\text {-Research and survey budget } \\
\text {-Employees turnover rate } \\
\text {-Inter-department trainings and meetings }\end{array}$} \\
\hline
\end{tabular}

Some of the measures found in our study were similar to the previous studies done for the Central Bank of Iran and Central Bank of Indonesia because of the similarity in the goals of the bank. However, the complete study was done under the precise framework of the Central Bank of Nepal, its acts, and the Nepalese banking environment. 
In expressing the new recommendations, the next step is to compile so as to implement the strategy in the bank and to achieve strategic goals. This study can also be transformed into applied research with proper planning. Based on the measures that were obtained in this study, the strategy map can be obtained through the same research via internal meetings with the cooperation of experienced consultants. In addition, this paper can lead a way towards the use of BSC and strategy mapping in a non-commercial and nonprofit organization in the future, especially in Nepal.

In order to achieve the strategic goals and change management, it is necessary to have a strategy and plan with a budget transplant. The successful link of planning with the budgeting process depends on the integrity of the organization and the implementation of long-term goals with short-term activities (budgeting) (Norton \& Peck, 2006).

For strategy implementation, the implementation of all the pillars of the organization is necessary. The organization's pillars based on the priority include all the roles of finance, human resource, structure, technology, and the task of the organization. Kaplan and Norton (2006) stated that successful strategy implementation takes place after compiling the strategy map, setting indicators, and proper budgeting improvement using the necessary personnel and technology.

\section{References:}

1. Abofaied, A. (2017). Evaluation of bank's performance by using balanced scorecard: Practical study in Libyan environment. International Journal of Business and Management, $V$ (1), 1-14. https://doi.org/10.20472/bm.2017.5.1.001

2. Aranda, C., \& Arellano, J. (2010). Consensus and link structure in strategic performance measurement systems: A field study. Journal of Management Accounting Research, 22(1), 271-299. https://doi.org/10.2308/jmar.2010.22.1.271

3. Banker, R. D., Chang, H., \& Pizzini, M. J. (2004). The balanced scorecard: Judgmental effects of performance measures linked to strategy. The Accounting Review, 79(1), 1-23. https://doi.org/10.2308/accr.2004.79.1.1

4. Fago, G. (2010). Performance measurement using balance scorecardA case of Nepal. Management Dynamics-A Journal on Management and Economics (2010) Vol, 14(1).

5. Frigo, M. L., Pustoring, P. G., \& Krull JR., G. W. (2000, Spring). The balanced scorecard for community banks: Translating strategy into action. Bank Accounting \& Finance, 13(3), 17. 
6. Hamdy, A. (2018). Balance scorecard role in competitive advantage of Egyptian banking sector. The Business \& Management Review, 9(3), 424-434.

7. Kalika, S. N. (2019). Evolutionary overview of central banking in Nepal: An account of law and practice. Management Dynamics, 22(1), 107-120. https://doi.org/10.3126/md.v22i1.30244

8. Kaplan, R. S. (2009). Conceptual foundations of the balanced scorecard. Handbooks of Management Accounting Research, 3, 12531269.

9. Kaplan, R. S., \& Norton, D. P. (1996). Using the balanced scorecard as a strategic management system. Harvard Business Review Press.

10. Kaplan, R. S., \& Norton, D. P. (2004). Strategy maps: Converting intangible assets into tangible outcomes (1st ed.). Harvard Business Review Press.

11. Kaplan, R. S., \& Norton, D. P. (2005). The balanced scorecard: measures that drive performance. Harvard Business Review, 83(7), 172.

12. Kaplan, R. S., \& Norton, D. P. (2006). Alignment: Using the balanced scorecard to create corporate synergies. Harvard Business Review Press.

13. Littler, K., Aisthorpe, P., Hudson, R., \& Keasey, K. (2000). A new approach to linking strategy formulation and strategy implementation: An example from the UK banking sector. International Journal of Information Management, 20(6), 411-428. https://doi.org/10.1016/s0268-4012(00)00036-0

14. Nepal Rastra Bank. (2020, November 13). About. नेपाल राष्ट्र बैंक. https://www.nrb.org.np/about/

15. Norton, D., \& Peck, P. (2006). Linking operations to strategy and budget. Balanced Scorecard Report, Harvard Business Review, 16-20.

16. Pakurár, M., Haddad, H., Popp, J., Khan, T., \& Oláh, J. (2019). Supply chain integration, organizational performance and balanced scorecard: An empirical study of the banking sector in Jordan. Journal of International Studies Vol, 12(2).

17. Quezada, L. E., Cordova, F. M., Palominos, P., Godoy, K., \& Ross, J. (2009). Method for identifying strategic objectives in strategy maps. International Journal of Production Economics, 122(1), 492-500. https://doi.org/10.1016/j.ijpe.2009.06.019

18. Rajab-Baigy, M., Foruzandeh, L., Mortazavi, M., \& Bigdeli, A. (2011). Strategy map creation using a balanced scorecard model case study: Central bank of Iran. European Journal of Economics, Finance and Administrative Sciences, (36). 
19. Scholey, C., \& Schobel, K. (2016). Performance measurement for nonprofit organizations. The Balanced Scorecard as an approach.

20. Teresiene, D. (2018). Performance measurement issues in central banks. Entrepreneurship and Sustainability Issues, 6 (1), pp.176189. 〈10.9770/jesi.2018.6.1(12)〉. 〈hal-02121128〉

21. Wu, H.-Y. (2012). Constructing a strategy map for banking institutions with key performance indicators of the balanced scorecard. Evaluation and Program Planning, 35(3), 303-320. https://doi.org/10.1016/j.evalprogplan.2011.11.009

22. Wu, H.-Y., Lin, Y.-K., \& Chang, C.-H. (2011). Performance evaluation of extension education centers in universities based on the balanced scorecard. Evaluation and Program Planning, 34(1), 37-50. https://doi.org/10.1016/j.evalprogplan.2010.06.001

23. Zhang, Y., \& Li, L. (2009). Study on balanced scorecard of commercial bank in performance management system. Proceedings. The 2009 International Symposium on Web Information Systems and Applications (WISA 2009) (p. 206). Academy Publisher. 